\title{
STUDIES ON DE MATERIA MEDICA OF DIOSCORIDES IN THE ISLAMIC ERA
}

\author{
Rıfat Vedat Yildirim (Lecturer, PhD) \\ Baskent University, Faculty of Medicine Ankara, Turkey \\ rvyildirim@hotmail.com
}

Received: 16 february 2012; Accepted: 12 november 2012.

Citation / Cómo citar este artículo: Yildirim, Rifat Vedat (2013), "Studies on De Materia Medica of Dioscorides in the Islamic era". Asclepio 65 (1): p007. doi: http://dx.doi.org/10.3989/asclepio.2013.07

\footnotetext{
* This article is a part of my master's thesis (See: Yıldırım, Rıfat Vedat (2003), “Dioskorides' in Materia Medica'sı ve Türk İslâm Tabâbeti [Materia Medica of Dioscorides and Turk-Islamic Medicine]", Yeni Tıp Tarihi Araştırmaları [The New History of Medicine Studies], 9, p. 383-479.)
}

\begin{abstract}
Pedanius Dioscorides was a Roman army surgeon in the first century A.D. His great work called De Materia Medica is widely accepted as the foremost pharmaceutical source of antiquity. Dioscorides was the originator of materia medica (pharmacology), and he took advantage of his extensive travels to study plants. Dioscorides was considered a major authority on simple drugs for sixteen centuries. De Materia Medica served as a corner stone for both western and eastern pharmaceutical and herbal writing, and was translated into Syriac, Arabic, and Persian, as well as Latin. The particular characteristic of medical therapy in the Medieval Period was the extensive employment of drugs of all kinds. For this reason, Dioscorides' De Materia Medica was not only studied closely, but it also became a text book that TurkIslamic scientists frequently referred to in their writings.
\end{abstract}

KEY WORDS: Dioscorides; De Materia Medica; Islamic Physicians.

\section{ESTUDIOS SOBRE DE MATERIA MEDICA DE DIOSCÓRIDES EN LA ERA ISLÁMICA}

RESUMEN: Pedanius Dioscórides fue médico cirujano en el ejército romano en el siglo I d.C. Su gran obra llamada De Materia Medica es conocida como la principal fuente de farmacopea de la antigüedad. Dioscórides fue el inventor de la materia medica, y aprovechó sus extensos viajes para dedicarse al estudio de las plantas. Dioscórides fue considerado una eminencia en el tema de las drogas de origen natural a lo largo de dieciséis siglos. De Materia Medica sirvió como piedra angular para los textos farmacéuticos y herbarios tanto en occidente como en oriente y fue traducida al siríaco, árabe y persa, además de al latín. La particular característica de la terapia médica en la época medieval fue el uso extensivo de todo tipo de drogas. Por esta razón, además de estudiarse minuciosamente, De Materia Medica de Dioscórides se convirtió también en un libro de texto al que frecuentemente hacían referencia los científicos turco-islámicos en sus escrituras.

PALABRAS CLAVE: Dioscórides; De Materia Medica; Médicos islámicos.

Copyright: (c) 2013 CSIC. This is an open-access article distributed under the terms of the Creative Commons Attribution-Non Commercial (by-nc) Spain 3.0 License. 


\section{INTRODUCTION}

Dioscorides was born in the first century A.D. in the Cilicia Region of Anatolia (Anazarba, near Adana of modern-day Turkey). It is known that he was a military physician in the Roman Army during the period of the Roman Emperors Caligula (37-41), Claudius (41-54) and Nero (54-68). His full name was Pedanius Dioscorides. He had vast medical knowledge, and showed great interest in botanical sciences as well as in pharmacognosy. He had the opportunity to study the plants of many different regions while traveling with the Roman Army, and wrote the most important text on botany and pharmacognosy. He traveled extensively throughout Anatolia, Egypt, Arabia, Persia, Gallia, North Africa and Caucasia.

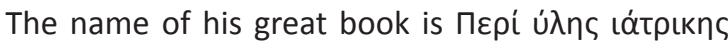
(Peri hyles iatrikes) in Greek. But this monumental work is more widely known by its Latin name, De $\mathrm{Ma}$ -

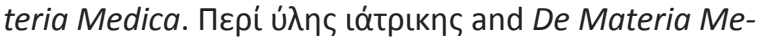
dica mean "On Medical Materials". De Materia Medica includes more than 600 herbal drugs, about 35 drugs from animal sources, and about 90 drugs prepared with minerals, most of which are depicted in paintings. In addition, it includes detailed information about those drugs, such as their places and methods of cultivation, botanical descriptions, medical effects, methods of use, side effects, dosages, veterinary usage and non-medical usage (Gunther, 1968, p. 1).

De Materia Medica consists of five books. In its English version, which was translated by John Goodyer in 1655 and was prepared by R. Gunther, aromatic plants, oils, ointments, trees and their juice, resin and fruits are mentioned in the first book; drugs from animal sources, cereals and vegetables are mentioned in the second book; roots and their juice, leaves and seeds are mentioned in the third and fourth books; grapes, different types of wine and minerals are mentioned in the fifth book.

\section{DE MATERIA MEDICA AND ITS FIRST TRANSLA- TIONS IN THE ISLAMIC ERA}

De Materia Medica was translated from Greek to the Arabic and Syriac languages several times during the translation movement of the Islamic science period ( $8^{\text {th }}$ century). Thus it became available to the scientists of the Islamic societies.

The translation of De Materia Medica was a very difficult study in terms of botanical science. Because Dioscorides wrote his book while travelling throughout very extensive regions, it was very difficult to find a proper equivalent name for the plants in the translated languages. The translators could not find Arabic and Syriac synonyms for the drugs Dioscorides made reference to. Stephanos ibn Basilos did not translate all the drug names. Rather, he chose to transcribe many of the Greek drug names to the Arabic alphabet. Since the botanical nomenclature in the Arabic language was not sufficient to translate all of the drugs in De Materia Medica of Dioscorides, the translators had to reformulate the Arabic botanical nomenclature. Thus, an extensive Arabic botanical nomenclature was developed through the efforts of translating De Materia Medica. During the Middle Ages, Dioscorides was remembered largely through aphorisms and the magical properties of drugs. Due to the fact that many of the Islamic writers on medicine were interested in simple drugs and their properties, improved versions of this monumental work were made available from time to time, especially in the Western Caliphate.

Until the $12^{\text {th }}$ century, the De Materia Medica translators in the Islamic culture society were:

2.1. Gabriel b. Bocht-Ichô: The first known and the most distinguished Syriac translation of De Materia Medica from its original Greek version was carried out by Gabriel b. Bocht-Ichô ${ }^{1}$ in the $9^{\text {th }}$ century (Şehsuvaroğlu, 1961, p. 39). However, Ünver notes that this translation was made by Bocht-Ichô b. Gabriel. ${ }^{2}$ Ünver also writes that:

"There is a Dioscorides copy registered in Ahmed III Library (2147 a). In its preface, it is written that this version was translated by Bocht-Ichô b. Gabriel from Greek to Syriac. Afterwards, all Arabic translations of De Materia Medica were made from this Syriac version." (Ünver, 1941, p. 130).

2.2. Stephanos ibn Basilos (Istifan bin Basil): Another Arabic translation of De Materia Medica was made by Stephanos ibn Basilos during the period of Mutavakkil b. Abbas (847-861), the Abbasid Calif (Arnaldez, 1978, p. 254-255). According to Arnaldez, Stephanos ibn Basilos was the first De Materia Medica translator (Arnaldez, 1978, p. 254-255). According to Ünver (Ünver, 1941, p. 130) and Şehsuvaroğlu (Şehsuvaroğlu, 1961, p. 39), Stephanos ibn Basilos translated De Materia Medica to Arabic, and his tutor Huneyn b. Ishaq ${ }^{3}$ (813-873) checked and corrected this translation. According to O'Leary, Stephanos ibn Basilos made the Syriac translation and Huneyn bin Ishaq made its Arabic translation (O'Leary, 1948, p. 169170). The publisher Fuad Sayyid cited Kashf al-Zunun ${ }^{4}$ of Katib Chalabi in the footnote of Ibn Djuldjul's Tabakat al-atibba wa al-hukema [The Degrees of Physicians and Scholars ].

Ibn Djuldjul wrote a book called "Tafsiru asma'il adwiyat al-mufrada min kitabi Dioskorides [The Interpretation of the Names of Simple Drugs in the Book of Dioscorides]". At the beginning of this book he said that: "This book of Dioscorides was translated in Bagdad in the period of Mutawakkil the Abbasid Calif. The 
translator was Stephanos ibn Basilos. He translated this book from Greek to Arabic. But he did not know the Arabic meanings of all the Greek words, so he did not translate the book in its entirety. He hoped that someone would fill in these gaps after him. Huneyn b. Ishaq checked and corrected this translation and gave his permission for it to be distributed." (Ibn Djuldjul, 1955, p. 21, footnote 7).

2.3. Huneyn b. Ibrahim b. El-Hasan b. Hurshid etTabari en-Natili: Huneyn b. Ibrahim b. El-Hasan b. Hurshid et-Tabari en-Natili (died 990) made another De Materia Medica translation for Prince Abu Ali AlSencuri in the $10^{\text {th }}$ century (O'Leary, 1948, p. 169-170). Natili studied the text of Stephanos ibn Basilos and Huneyn b. Ishaq. However, he was not well-cognizant of the Greek language, and his intervention of Stephanos' text was restricted. In this work, Natili wrote the Arabic names of the drugs together with their Greek transcriptions, and he partially changed the settlings of drugs. He rarely added Persian plant names which were in use in his territory and in his life time.

2.4. Priest Nicolas: Some sources indicate that Priest Nicolas made a De Materia Medica translation into Arabic from Greek in Cordoba (Andalusia), during the period of Calif Nasir Abd al-Rahman III (891-961) in the $10^{\text {th }}$ century (Ünver, 1941, p. 130; Ibn Djuldjul, 1955, p. 21, footnote 7). There was an illustrated Greek version of De Materia Medica among the gifts which the Byzantine Emperor Constantin VII (905959) ${ }^{5}$ sent to Calif Nasir Abd al-Rahman III in 949 (Ibn Djuldjul, 1955, p. 21, footnote 7). Dioscorides' De Materia Medica attracted great attention in Cordoba. But in those days Greek was not a well-known language in Cordoba. The Calif needed a translator who would make this great work given to him by the Emperor accessible. Thus, in 951 the Emperor sent the Priest Nicolas to Cordoba. Nicolas not only translated $\mathrm{De} M \mathrm{M}-$ teria Medica from Greek to Arabic, he also taught the Greek language in Cordoba. Some court physicians of the Calif including Hasdai ibn Shaprut, Abd al-Rahman b. Ishaq and Ibn Al-Haisem worked together with $\mathrm{Ni}$ cola (Ibn Djuldjul, 1955, p. 21, footnote 7; Ullmann, 1970, p. 260). Their purpose was to determine and identify the plants which had not been clearly identified by Stephanos ibn Basilos and Huneyn b. Ishaq (Ullmann, 1970, p. 260). According to O'Leary, Nicola's translation was better than the previous translations and much improved (O'Leary, 1948, p. 171).

2.5. Abu Salim from Malatya: Abu Salim from Malatya made another De Materia Medica translation in the period of Prince of Diyarbekir Kutlug Bey from Artukoglu [Artuqid] in the $12^{\text {th }}$ century (Ünver, 1941, p. 130; Şehsuvaroğlu, 1961, p. 40, footnote 4). This translation was made from the original Greek version of De Materia Medica. After Abu Salim had finished the translation, it was read to the Prince. Most scholars thought it was mistranslated, and the mission was handed over to Mihran b. Mansur b. Mihran al-Mesihi (Ünver, 1941, p. 130-131).

2.6. Mihran b. Mansur b. Mihran al-Mesihi: The Mihran b. Mansur b. Mihran al-Mesihi's translation was based on the text of the Syriac translation by Huneyn b. Ishaq (Ünver, 1941, p. 130-131). Incidentally, when Mihran's translation is compared with the text by Stephanos ibn Basilos, some differences regarding plant names and medical terminology are perceived (Ullmann, 1970, p. 262). For example, the word tó píyos [chill, shiver, shudder] was translated by Stephanos ibn Basilos as al-nāfid, and by Mihran as al-quša'rīra. The word $\eta \cup \delta \rho o \kappa n ́ \lambda \eta$ [hydrocele] was translated by Stephanos ibn Basilos as udrat al-mā, and by Mihran as qïla mä'îya (Ullmann, 1970, p. 262).

\section{DE MATERIA MEDICA MANUSCRIPTS IN MODERN TURKEY}

3.1 Arabic Manuscripts of De Materia Medica: Arabic translations of De Materia Medica were received the name of Kitab al-Hashaish fi al-Tibb [The Book of Medical Herbs]. Three copies of its Arabic versions are in the Istanbul Sulaimaniya Library, registered in Ayasofya No: 3702-3703-3704.

3.1.1. Kitab al-Hashaish fi al-Tibb Number 3702: This manuscript was supposedly copied in 1224 (Tekiner, 2009, p. 1-2). Copy number 3702 consists of five articles (books) including a total of 187 folios. It contains the following expression at the beginning: (Dioscorides, 1224a, fl. 1a)

$$
\begin{aligned}
& \text { "كتاب ديسقوريدس العين زربى فى هيولى اصلى }
\end{aligned}
$$

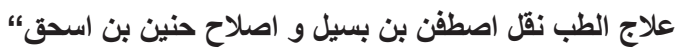

It reads: "Kitab Diskorides al-Ayn Zarbi fi Hayula Ilac et-Tibb naql Istifan bin Basil islah Huneyn bin Ishaq (Book of Dioscorides from Anazarba named Hayula llac et-Tibb [Main Matters of Medicines] translated by Istefan b. Basil, and corrected by Huneyn bin Ishaq)". There are some differences between this Arabic version and the English version translated by John Goodyer. Grapes, the different types of wine and minerals were mentioned in the third article of the Arabic manuscript. Venomous animals and their bites and deadly drugs were mentioned in the fifth article. In this Arabic version, some drug names were not translated but the original Greek names were written in Arabic letters, while other drug names were fully translated into Arabic (Dioscorides, 1224a).

3.1.2. Kitab al-Hashaish Number 3703: This manuscript was also supposedly copied in 1224 (Tekiner, 2009 , p. 2). At the beginning of version 3703 of Kitab al-Hashaish, it is written that this copy was donated 
by Sultan Mahmut II (1785-1839). The first two folios of the manuscript are missing. In this version, there are some bird and animal illustrations besides the plant illustrations, unlike in version 3702. Another difference from version is that version 3703 consists of seven articles in a total of 155 folios. In the sixth article, useful and harmful drugs are mentioned. The seventh article mentions animals and their deadly poisons. There is yet another chapter at the end of this version, added by Huneyn b. Ishaq, mentioning grapes. We learn from a note at the end that the manuscripter of this version was Abd-Allah b. Fadhil. In this manuscript many of the drug names were not translated, but the original Greek words were written in Arabic letters (Dioscorides, 1224b).

3.1.3. Kitab al-Hashaish Number 3704: This dating of this manuscript is uncertain. It was supposedly copied sometime between the $10^{\text {th }}$ and $12^{\text {th }}$ centuries (Tekiner, 2009, p. 3). At the beginning of version 3704 of Kitab al-Hashaish it is written that this copy was also donated by Sultan Mahmut II. This version consists of six articles, unlike other Sulaimaniya copies. Another difference from the other versions lies in that there are brief informative notes under the illustrations of the third article. Also differing from the other versions, there is a note at the beginning of the fifth article: "My friend Areius, I mentioned oils, spices, fruits, legumes, roots, different kinds of juice and seeds in four articles before. In this article, I will mention different kinds of wine and mineral drugs." In the sixth article, animals, poisonous animals, medicinal parts of animals, wool, milk, bile juice, brain and suet are mentioned (Dioscorides, X-XII Century).

3.2. Kitab al-Hashaish fi al-Tıbb in the Topkapi Palace Library: There is another Arabic translation of De Materia Medica in the Topkapi Palace Library in Istanbul. This manuscript dates from approximately 1228 . Its catalogue number is A.2127, and it has 274 folios (Tekiner, 2009, p. 4). It is known that it was translated by Mihran b. Mansur b. Mihran al-Mesihi, and was manuscript by Abu Yusuf Behnam Ibn Musa Ibn Yusuf al-Musuli.

3.3. Persian Manuscript of De Materia Medica: There is also a Persian version of De Materia Medica in the Topkapi Palace Library, dating from 1462. Its catalogue number is 2147, and it has 203 folios (Tekiner, 2009 , p. 5). It was translated from Mihran b. Mansur's Arabic translation by Ali ibn Sherif al-Huseyni. It is known that the translator also manuscript this monumental work.

3.4. Turkish Manuscripts of De Materia Medica: There is an Ottoman Turkish version of De Materia Medica in the Istanbul University Manuscripts Library. It is dated in 1858, and consists of 294 folios (Tekiner, 2009 , p. 5). It was translated from Mattioli's Italian translation by Osman bin Abdurrahman, and received the name of Kitab al-Nebat [The Book of Plants]. This manuscript is a copy of the original Ottoman translation. Its original translation was made in 1777 (see also section 5). It was copied (manuscript) by Nuri Uskudari al-Sayyid Ali Riza (Tekiner, 2009, p. 5).

\section{STUDIES ON DE MATERIA MEDICA IN THE ISLAMIC ERA}

Following the translation movement of the Islamic science period, in approximately the $9^{\text {th }}$ century, when scientists began to write their own original books on simple drugs, De Materia Medica was widely used. In the footnote of Ibn Djuldjul's Tabakat al-atibba wa alhükema [The Degrees of Physicians and Scholars], the publisher Fuad Sayyid indicates that Islamic writers often referred to De Materia Medica in their books: (Ibn Djuldjul, 1955, p. 21, footnote 7).

4.1. Ibn Djuldjul: Ibn Djuldjul wrote a great work called Tafsiru Asma al Adviyat al-Mufrede min Kitabi Dioskorides [Explanation of the Names of Simple Drugs in the Book of Dioscorides]. Unfortunately the complete book is lost, yet a small part of it can be found in Madrid Library Number 233 (Ibn Djuldjul, 1955, p. 12). There is some information about a manuscript of this book, scribed in 1294, in the appendix of Eb Subat's Catalogue (p. 38), yet there is no information about the whereabouts of this copy. Khafiqi and Ibn Baitar also cited Ibn Djuldjul's study on Dioscorides (Ibn Djuldjul, 1955, p. 13).

4.2. Ibn Sina (died 1037): In Al-Qanun fi al-TIbb [The Canon of Medicine], many items in the chapter about simple drugs were taken from De Materia Medica.

For example, mentioning the plant named iklil al melik (yellow sweetclover), Ibn Sina writes: "Dioscorides says that some people call it "isqifon" (ايسقيفون). It is a dry plant; it has many branches, and it is quadratic. Its color is whitish. Its leaves look like quince, are slightly rigid and plumed. It grows on rigid soil... Dioscorides says that the best variety of that plant has a color like saffron and it has a strong fragrance." (Ibn Sina, 1833-1834, p. 243).

In the chapter on uqhuvan (oxeye daisy), Ibn Sina cites Dioscorides as follows: "Dioscorides says some people refer to it as "amaryon" (الماريون), others refer to it as "qorinbon" (قورينبون), and yet others refer to it as "arqismon" (ارقسمون). Its leaves look like coriander's. Its flowers are white and round. It has a strong smell and it tastes bitter..." (Ibn Sina, 18331834, p. 250.

4.3. Ali b. Ridvan (the Egyptian, died 1061): He refers to Dioscorides in his own book on simple drugs. 
4.4. Ibn Wafid al-Andulusi (Abd Al-Rahman b. Muhammed b. Abd Al-Kabir, died 1074): He wrote a book, Al-Adwiyat al-Mufrada [The Simple Drugs], compiled mostly from the works of Dioscorides and Galenos.

4.5. Al Sherif al-Idrisi (died 1165): He wrote a book named Al-Jami'li Sifati Ashtati al-Nabat [The Collection of Properties of Plant Types], referring to Dioscorides' studies, and also added some plants not mentioned by Dioscorides.

4.6. Abu Jafar Ahmed b. Muhammed al-Khafiqi (died 1165): He wrote a book named Kitab-I Jami alMufradat [The Book of Simple Drugs] by examining the studies of Dioscorides and Galenos. Ibn al-Ibri later shortened this book, and renamed it Muntahab-i Jami al-Mufradat [The Selected Collection of Simple Drugs].

4.7. Abd Al-Latif al Baghdadi (died 1232): He wrote a book about Dioscorides called Intizaat min Kitabi Dioskorides fi Sifat al-Hashaish [The Regularity of Properties of Plants in Book of Dioscorides].

4.8. Abu al-Abbas b. Rumiyye (died 1239): He wrote a book about Dioscorides called Tafsiru Asma al Adwiyat al-Mufrada min Kitabi Dioskorides [Explanation the Names of Simple Drugs in the Book of Dioscorides].

4.9. Ziyauddin b. Al-Baitar (Ibn Baitar) (died 1248): He gathered five of Dioscorides' books under the name of Al-Jami' fi al-Adwiyat al-Mufrada (or Jâmi al mufradat al-adwiya wa al-agdiya) [The Collection of Simple Drugs] in 1232.

In this book, there are 2,353 simple drugs in alphabetical order (Kaya, 1999, p. 526-527). The earliest Turkish translation of this book dates back to the reign of Aydınoğlu Umur Bey (1340-1348), to whom the translation was dedicated. The drug names are given in Turkish and Greek, in alphabetical order. Its second translation to Turkish is by Physician Rindani, in 1681. He called this book Risale-i levazimu't-tibb min sharh Ibn Baitar [A Booklet about Medical Supplies Commented by Ibn Baitar] (Şehsuvaroğlu, 1970, p. 281282). A copy of this translation can be found in The Library of The Department of History of Medicine and Ethics, Istanbul University Istanbul Medical School, registered as T.Y. 68.

Here are some examples from this book, referring to Dioscorides:

In the section about mint: "Dioscorides, Ibn Wafid and Ibn Sina say that if it is ground and mixed with barley meal and applied as a poultice to the forehead, it heals headache from cold weather..." (Ibn Baitar, 1681, fl. 4b).
In the section about sesame: "Dioscorides and Ibn Wafid say that if sesame is ground and mixed with rose oil and wrapped around the head, it heals suninduced headache..." (Ibn Baitar, 1681, fl. 5b).

In the section about black cumin: "Dioscorides says that if black cumin is soaked in vinegar throughout one day and one night, is then ground and mixed with rose oil and dripped into the nose, it heals chronic headache from cold weather..." (Ibn Baitar, 1681, fl. 6a).

In the section about bull horn: "Dioscorides, Rhases and Galenos say bull horn that is burned and its ashes pounded with water, produces a mixture that is helpful if someone who has a bleeding throat drinks it, and this is well tested..." (Ibn Baitar, 1681, fl. 124a).

And also in the section on petty morel, the following expression is eye catching: "Rhases, Dioscorides, Ibn Butlan say that drinking one misqal ${ }^{6}$ of petty morel boiled with hydromel is helpful for heart palpitations due to cold weather. It strengthens the chest, the lungs and stomach, and removes halitosis..." (Ibn Baitar, 1681, fl. 167a).

4.10. Davud al-Antaki (died 1599): His book Tadzkiratul ulil-Albab [A Booklet On Subjects] is based on Dioscorides' studies.

This list is not limited to the above names. There are more Islamic writers who referred to De Materia Medica, including names such as Al-Biruni ${ }^{7}$ and Al-Razi ${ }^{8}$.

\section{DE MATERIA MEDICA IN THE OTTOMAN PERIOD}

During the Ottoman period, De Materia Medica was a basic source for simple drugs.

Risale-i Feizie fi Lugat al-Mufradat al-Tıbbiye [A Booklet by Ebulfeiz (name of the author) on The Dictionary about Simple Medicines] by Ebulfeiz Mustafa from the $17^{\text {th }}$ century is a good example in demonstrating Dioscorides' effect on Ottoman therapeutics (Aydın, 1998, p. 161). This book alphabetically records the Turkish and the Arabic names of herbal, animal and mineral drugs. A copy of it can be found in the Library of The Department of History of Medicine and Ethics, Istanbul Medical School, Istanbul University, No: Y.165 and 233. Some citations in this book from Dioscorides include:

"Tabak means fleabane in Turkish. It looks like liverwort. In the illustrated book of Dioscorides, it is described exactly the same as a plant with leaves that look like tobacco..." (Ebulfeiz Mustafa, 17. century, fl. $88 a-b)$.

From the item on qastran (betonika):

"Some of them call it "adjikidji" in Turkish; some of them call it "sokluk otu". But at the beginning of the fourth article of the illustrated book of Dioscori- 
des, it is mentioned in the illustration of qastran and is named "fetharotarokon" (فتحروطروقون). It provokes coldness. According to Dioscorides, Greeks call it "betoniki" and "semeranyon" and he described it as "betonika", which we use nowadays..." (Ebulfeiz Mustafa, 17. century, fl. 109a-b).

One of the books about simple drugs in the Ottoman Age was Mufredat al-Tibb [Simple Medicines] written by Fazlızade Mehmed in 1763. A copy of this book is in the Istanbul Sulaimaniya Library, registered in Hamidiye No: 1017. This book consists of two chapters besides the introduction. The simple drugs were mentioned in the first chapter (Aydın, 1998, p. 127). The writer referred to eighteen different sources including Ibn Sina, Rhazes, Hippocrates, Ibn Baitar and Dioscorides (Aydın, 1998, p. 135). The section on daphne is a good example of citations from Dioscorides:

"...and Ibn Baitar said that its leaves were known in Andalusia as "aris mazeriun", "maderyun" and also as "mazer". There were a number of names, but al-Hasil Abd-Allah b. Salih and Galenos and Dioscorides and others said, that these three plants were the same..." (Aydın, 1998, p. 139).

There are also two other Dioscorides citations in this book. The first of them is in the section on styrax: "There is much controversy about istirak (صطر (ص) (ص) In credited books it receives the name "styrax". But it is controversial that "istirak" is "styrax" or "frankincense". In Greek books, Dioscorides said "istirak" is "styrax"." (Fazlızade Mehmed, 1763, fl. 6a).

The second example is the section on cupressus: "According to Dioscorides, the nature of cupressus (حمغ السرو) is hot and wet." (Fazlızade Mehmed, 1763, fl. $76 b)$.

P. A. Matthioli (1500-1577) wrote a book called Pedacio Dioscoride Anazarbeo Della Materia Medicinale. Some parts of this book were translated to Ottoman Turkish by Osman b. Abdurrahman in 1777 (Aydın, 1998, p. 144). This translation was called Kitab al-Nebat [The Book of Plants]. It is the most important translation of De Materia Medica in the Ottoman period. Although the book of Dioscorides consists of five chapters, this translation includes only the first four chapters. Mattioli's Italian version of De Materia Medica is not in alphabetical order like the original version; but the translation includes catalogs, which facilitate the search for drugs. This characteristic feature of De Materia Medica was preserved during the Turkish translation, so these catalogs are user-friendly.
In the preface of this manuscript, the translator Osman b. Abdurrahman says that he gave Arabic, Turkish and Latin synonyms of some drugs, and only Arabic and Latin synonyms of others, Latin names of many of them and Bosnian and Greek synonyms of some of them (Aydın, 1998, p. 144). In addition to this, drug explanations are detailed and systematic. This manuscript is not illustrated, and the nature and the efficacies of the drugs were stated separately and manuscript with red ink. There are four chapters in these books which respectively consist of $119,126,146$, and 105 drugs (Aydın, 1998, p. 144). A copy of this manuscript is registered as number 19/1 in Istanbul University, Cerrahpaşa Medical Faculty, History of Medicine Museum.

\section{CONCLUSION}

De Materia Medica of Dioscorides is one of the earliest pharmaceutical works dealing with medicinal plants, animal parts and products, and minerals, and was accepted as an almost infallible source as late as the Renaissance period. The work of Dioscorides served as the corner stone for both western and eastern pharmaceutical and herbal writing for a period spanning 1,500 years. This monumental work was translated into Syriac, Arabic, and Persian as well as Latin, exerting a profound influence on the development of medicine in the Near East as well as in Europe. After the book of Theophrastus, De Materia Medica is the most comprehensive and systematic work on simple drugs. It was through the pioneering efforts of Arabs that The Greek Herbal of Pedanius Dioscorides was transmitted to mediaeval Europe. The special characteristics of Arabist therapy was the widespread employment of drugs of all kinds which is why De Materia Medica of Dioscorides was studied so closely. It was used extensively by many doctors and medical writers of the Eastern and the Western cultures. The fact that De Materia Medica of Dioscorides was a great source of information for other historic pharmaceutical works in the writings of Ibn Sina, al-Razi, Ibn Djuldjul, Ali bin Ridvan, al-Ghafiqi, Abdullatif al-Baghdadi, Ibn Baitar, al-Biruni and Davud al-Antaki who all used De Materia Medica of Dioscorides as a pharmaceutical source, and referred to Dioscorides in their books. Some of those writers wrote a treatise to explain the drug names cited in De Materia Medica. De Materia Medica also led to the constitution of a detailed Arabic botanical nomenclature. De Materia Medica was of considerable importance for Turk-Islamic medicine because Turk-Islamic physicians used this monumental book effectively and frequently. 


\section{NOTES}

1 Gabriel b. Bocht-Ichô (died 828) was a member of the BochtIchô family. He was raised as a physician by his father Bocht-Ichô II. He was the court physician of Calif Harun Al-Rashid an Calif Al-Ma'mun. He made great contributions to Islamic medicine through his many Arabic translations from the Greek, Syriac and Persian languages in Bait al-Hikma (Translation School in Baghdad). (See: Doğruyol, 1992, p. 379).

2 Bocht-Ichô b. Gabriel (died 870) was the sixth physician in the Bocht-Ichô family. When his father Gabriel b. Bocht-Ichô died, he became the court physician of Calif Mamun. (See: Bayat, 1992, p. 379).

3 He was born in 766 A.D. His native languages were Arabic and Syriac. He learned medicine from Yuhanna bin Masawaih (director of Bait al-Hikma). He learned Greek in Alexandria. He worked in Bait al-Hikma and translated over 100 books to the Arabic language. He died in 877. (See: Sami, 1891, p. 1993-1996).

\section{BIBLIOGRAPHY}

Arnaldez, Roger (1978), "Istifan b. Basil”, In: Bosworth, Clifford Edmund; Donzel, Emeri; Lewis, Bernard; Pellat, Christian (coord.), The Encyclopaedia of Islam, 4, p. 254-255.

Aydın, Mukerrem Bedizel (1998), “18. Yüzyıla Ait Türkçe Müfredât Kitapları ve Türk Tıp Tarihindeki Yeri [Turkish Books On Simple Drugs in 18th Century and Their Place in Turkish History of Medicine], Istanbul University Cerrahpaşa Medical Faculty, Department of History of Medicine and Ethics, Doctorate Thesis", In: Tıp Tarihi Araştırmaları [History of Medical Studies], 7, p. 55-168.

Bayat, Ali Haydar (1992), "Buhtîşû' b. Cibrâîl”, In: Türkiye Diyanet Vakfi İslâm Ansiklopedisi [Encyclopaedia of Islam of the Turkish Religious Affairs Foundation], 6, p. 379.

Dioscorides, Pedanius (1224a), Kitab al-Hashaish fi al-Tıbb [The Book of Medical Herbs] (Sulaimaniya Library, Ayasofya No.3702).

Dioscorides, Pedanius (1224b), Kitab al-Hashaish fi al-Tıbb [The Book of Medical Herbs] (Sulaimaniya Library, Ayasofya No.3703).

Dioscorides, Pedanius (X-XII Century), Kitab al-Hashaish fi al-Tıbb [The Book of Medical Herbs] (Sulaimaniya Library, Ayasofya No.3704).

Doğruyol, Hasan (1992), "Cibrâîl b. Buhtîsû", In: Türkiye Diyanet Vakfi islâm Ansiklopedisi [Encyclopaedia of Islam of the Turkish Religious Affairs Foundation], 6, p. 379.

Ebulfeiz Mustafa (17. century), Risale-i Feizie fi Lugat al-Mufradat al-Tibbiye (Library of Istanbul University, Istanbul Medical Faculty, The Department of History of Medicine and Ethics, No: Y.165 and 233).

Fazlızade Mehmed (1763), Mufredat al-Tibb, Istanbul Sulaimaniya Library, Hamidie No. 1017.

Gunther, Robert (1968), The Greek Herbal of Dioscorides, Illustrated by A Byzantine A.D. 512, Englished by John Goodyer A.D. 1655 Edited and First Printed A.D. 1933, Facsimile of The 1934 Edition, London-NewYork.
4 The full name of this book is Kashf al-Zunun an Asami al-Kutubi wa al-Funun [The Eliminations of Suspicions About Names of Books and Sciences].

5 Katib Chalabi, in his work Kashf al-Zunun, cites the name of the monarch as the Byzantine Emperor Ermanius. (See: Ibn Djuldjul, 1955, p. 21, footnote 7).

6 A unit of weight in the Islamic world, usually taken as equivalent to 4.25 grams, used especially to weigh precious metals.

7 Alberuni, Aliboron (writer of Kitab Al-Saydana fi Al-TIbb) (See: Kahya and Erdemir, 2000, p. 31).

8 Rhazes (writer of Al-Hawi) (See: Ullmann,1970, p. 261).

Ibn Baitar (1681), Risale-i levazımu't-tıbb min sharh Ibn Baitar [A Booklet about Medical Supplies Commented by Ibn Baitar] (Trans.: Hekim Rindani)

Ibn Djuldjul (1955), Tabakat al-Atibba ve al Hukema [The Degrees of Physicians and Scholars] (Publisher: Sayyid, Fuad), Cairo.

Ibn Sina (1833-1834), Qanun [Canon], Bulak Printing Press, vol. I.

Kahya, Esin; Erdemir, Ayşegül Demirhan (2000), Bilimin Işığında Osmanlıdan Cumhuriyete Tıp ve Sağlık Kurumları [Medical and Health Institutions in Scientific Enlightenment, From Ottoman Times To the Turkish Republic], Ankara, Türkiye Diyanet Vakfi Yayınları [Turkish Religious Affairs Foundation Press].

Kaya, Mahmut (1999), "Ibn al-Baytar", In: Türkiye Diyanet Vakf İslâm Ansiklopedisi [Encyclopaedia of Islam of the Turkish Religious Affairs Foundation], 20, p. 526-527.

O'Leary, De Lacy (1948), How Greek Science Passed To The Arabs, London, Routledge and Kegan Paul.

Sami, Şemseddin (1891), "Huneyn b. Ishak", In: Kamus al-Alam [The Dictionary of Science], 3, p. 1993-1996.

Şehsuvaroğlu, Bedi (1961), “Dioskorides' in Materia Medica' sı ve Tesirleri [Materia Medica of Dioscorides and Its Impressions]", Eczacılık Bülteni [Bulletin of Pharmacy], 3, p. 37-45.

Sehsuvaroğlu, Bedi (1970), Eczacılık Tarihi Dersleri [The History of Pharmacy Lessons], Istanbul, Istanbul Universitesi Yayınları [Istanbul University Press].

Tekiner, Halil (2009), Dioscorides' Materia Medica Manuscripts in Turkey, at: http://www.pharmaziegeschichte.at/ichp2009/vortraege/vortraege_volltext_pdf/L07.pdf (retrieved on 12/11/2012)

Ullmann, Manfred (1970), Die Medizin im Islam [The Islamic Medicine], Leiden-Köln.

Ünver, Süheyl (1941), “İstanbul’da Dioskorides Eserleri ve Arttklılar [Dioscorides Monuments in Istanbul and Artuqids]", Dirim, 1-2, p. 129-133. 